\title{
PUBIC SYMPHYSIS DIASTASIS IN TWIN PREGNANCY
}

\section{DIJASTAZA SIMFIZE U BLIZANAČKOJ TRUDNOĆI}

\author{
Vesna Gall, Egon Kruezi, Ivka Djaković, Vesna Košec
}

University Clinic for Gynecology and Obstetrics, Sestre Milosrdnice University Hospital Center; Klinika za ženske bolesti i porodništvo, Klinički bolnički centar Sestre Milosrdnice

Corresponding author / Adresa autora za dopisivanje:

Kruezi Egon, dr.med.

University Clinic for Gynecology and Obstetrics / Klinika za ženske bolesti i porodništvo

Sestre Milosrdnice University Hospital Center / Klinički bolnički centar Sestre Milosrdnice

Ulica kneza Ljudevita Posavskog 36B

10000 Zagreb

Croatia / Hrvatska

E-mail / e-pošta: egonkruezi@gmail.com

Received / Primljeno: October 17, 2019/ 17. 10. 2019.

Accepted / Prihvaćeno: December 11, 2020 / 11. 12. 2020.

\section{Abstract}

Pubic symphysis diastasis is a rare pregnancy complication whose exact incidence is still not known, but it is estimated to be in the range of 1:300 to 1:30,000 pregnancies. It is defined as a distance between the two pubic bones or an interpubic gap greater than $10 \mathrm{~mm}$ with typical presentation. Typical symptoms of diastasis symphysis are pain in the symphyseal region that radiates to the lower back and thighs, waddling gait, painful movement, reduced mobility, and, rarely, urinary retention. In this case report we present a case of antepartum pubic symphysis diastasis diagnosed by palpation during a pelvic exam in a multiparous woman with a twin pregnancy. The patient had an uneventful previous antenatal period; at a routine follow-up she reported symphyseal pain over a longer period with exacerbation in the previous three weeks, in addition to difficulty walking and staying in an upright position. On manual palpation a 10-mm interpubic gap was found and the patient was hospitalized. In view of the twin pregnancy and pubic symphysis diastasis it was decided that a cesarean section was the appropriate mode of delivery. A postoperative pelvic $\mathrm{X}$-ray showed an interpubic gap of $14 \mathrm{~mm}$. With regard to the simplicity and reliability of manual palpation in cases of suspected pubic symphysis diastasis, implementing palpation of the pubis in regular obstetrical practice would enable early recognition, immediate treatment, and a better outcome in the long term. Also, as there are no evidence-based guidelines considering antepartum pubic symphysis diastasis and each case is approached individually, a comprehensive investigation of this condition is needed in order to achieve standardization of practice.

Keywords: Pubic symphysis diastasis - diagnosis; Pubic symphysis - diagnostic imaging; Pelvic pain - etiology; Pregnancy complications - diagnosis; Palpation; Twin pregnancy; Radiography

\section{SAŽETAK}

Dijastaza simfize rijetka je komplikacija trudnoće čija točna incidencija još nije poznata, a procijenjena incidencija kreće se u rasponu od $1: 300$ do $1: 30.000$ trudnoća. Definira se kao udaljenost između dvije pubične kosti odnosno kao interpubični razmak veći od $10 \mathrm{~mm}$ s tipičnom kliničkom slikom. Tipični simptomi dijastaze simfize jesu bol u području simfize koja se širi u donji dio leđa i bedro, gegavi hod, bolno kretanje, smanjena pokretljivost i, rijetko, urinarna retencija. $\mathrm{U}$ ovom radu prikazujemo bolesnicu s antepartalnom dijastazom simfize, koja je dijagnosticirana manualnom palpacijom za vrijeme redovitoga ginekološkog pregleda. Višerotkinja s blizanačkom trudnoćom, koja dotad nije imala kompliciran tijek trudnoće, pri redovitom je pregledu navela da dulje osjeća bol u području simfize, uz pogoršanje tegoba u posljednja 3 tjedna te otežano hodanje i stajanje. Manualnom palpacijom otkriven je interpubični razmak od $10 \mathrm{~mm}$ te je trudnica hospitalizirana. S obzirom na blizanačku trudnoću i dijastazu simfize, odlučeno je da trudnoća bude dovršena elektivnim carskim rezom. Postoperativni rendgenogram (RDG) zdjelice pokazao je interpubični razmak od $14 \mathrm{~mm}$. Manualna palpacija jednostavna je i pouzdana metoda pa bi njezino uvođenje u svakodnevnu opstetričku praksu omogućilo rano otkrivanje dijastaze simfize, brži početak terapije i dugoročno bolji 
ishod. Također, budući da ne postoje znanstveno dokazane smjernice o zbrinjavanju antepartalne dijastaze simfize, nego se svakoj bolesnici pristupa individualizirano, potrebno je sveobuhvatno istraživanje ove patologije koje bi dovelo do standardiziranja prakse.

KLJUČNE RIJeČI: Dijastaza pubične simfize - dijagnoza; Pubična simfiza - dijagnostički slikovni prikaz; Zdjelična bol - etiologija; Komplikacije u trudnoći - dijagnoza; Palpation; Blizanačka trudnoća; Radiografija

\section{INTRODUCTION}

Pubic symphysis diastasis is a rare complication of pregnancy, whose exact incidence is still not known, but it is estimated to be in the range of 1:300 to 1:30,000 pregnancies (1-5). It is defined as a distance between the two pubic bones or an interpubic gap greater than $10 \mathrm{~mm}(6,7)$ with typical presentation. Typical symptoms of diastasis symphysis are pain in the symphyseal region that radiates to the lower back and thighs, waddling gait, painful movement, reduced mobility, and, rarely, urinary retention $(3,7)$. Mild enlargement of the interpubic gap occurs physiologically during pregnancy $(8,9)$, just like its subsequent regression to the pregravid state. However, the etiology and pathogenesis of a pathologic distension of the interpubic gap is not known. There is an assumed association between the hormone relaxin and this condition. Relaxin impacts ligaments and cartilaginous joints, which can cause symphyseal widening $(6,10,11)$. Also, there are some possible risk factors like multiparity, shoulder dystocia, macrosomic fetus, large fetal head, rapid progression of the second stage of labor and rapid descent of the presenting part, epidural anesthesia, and previous pelvic trauma (2). Treatment is usually conservative (wearing a pelvic belt, physiotherapeutic exercise, and rest) and, in rare instances, surgical $(3,7)$. In this report we present a case of antepartum pubic symphysis diastasis diagnosed by palpation during a pelvic exam in a multiparous woman with twin pregnancy.

\section{CASE REPORT}

A twenty-six-year-old multiparous woman, gravida 3, para 2, with twin pregnancy ( 2 chorions, 2 amnions), gestational age 31 weeks and 4 days $(31+4 / 7)$, weighing 75 kilograms (+9 in pregnancy) and 154 centimeters tall, had an uneventful previous antenatal period. At a routine follow-up she reported symphyseal pain over a longer period with exacerbation in the previous three weeks, in addition to difficulty walking and staying in an upright position. On manual palpation a $10-\mathrm{mm}$ separation of the interpubic gap was found and the patient was hospitalized. The only comorbidities in her medical history were mild anemia, treated with iron supplements, and thrombocytopenia known since childhood. During the hospital stay she was treated with conservative methods which included wearing a pelvic belt, physiotherapeutic exercise (strengthening of the pelvic floor and

\section{UVOD}

Dijastaza pubične simfize rijetka je komplikacija trudnoće čija točna incidencija još nije poznata, a procijenjena incidencija kreće se u rasponu od $1: 300$ do $1: 30.000$ trudnoća $(1-5)$. Definira se kao udaljenost između dvije pubične kosti odnosno kao interpubični razmak veći od $10 \mathrm{~mm}(6,7)$ s tipičnom kliničkom prezentacijom. Tipični simptomi dijastaze simfize jesu bol u području simfize s propagacijom $u$ donji dio leđa $i$ bedra, gegavi hod, bolno kretanje i smanjena pokretljivost te, rijetko, retencija urina $(3,7)$. Blago povećanje interpubičnog razmaka pojavljuje se psihološki za vrijeme trudnoće $(8,9)$, baš kao što dolazi do njegove naknadne regresije u stanje prije graviditeta, no etiologija i patogeneza patološke distenzije interpubičnog razmaka nisu poznate. Pretpostavlja se da postoji veza između hormona relaksina i ovog stanja. Relaksin utječe na ligamente i hrskavične zglobove koji mogu prouzročiti širenje simfize $(6,10,11)$. Postoje i neki mogući rizični čimbenici kao što su multiparitet, distocija ramena, makrosomni fetus, velika glava fetusa, brzo napredovanje druge faze porođaja i brzo spuštanje prezentacijskog dijela, epiduralna anestezija te prethodna trauma zdjelice (2). Liječenje je obično konzervativno (nošenje zdjeličnog pojasa, fizioterapeutske vježbe i odmor), a u rijetkim slučajevima kirurško (3, 7). U ovom radu prikazujemo višerotkinju s blizanačkom trudnoćom i antepartalnom dijastazom simfize koja je dijagnosticirana manualnom palpacijom za vrijeme redovitoga ginekološkog pregleda.

\section{PRIKAZ BOLESNICE}

Naša je bolesnica bila 26-godišnja višerotkinja (3 trudnoće, 2 porođaja) s blizanačkom trudnoćom (bikorijat, biamnijat) gestacijske dobi od 31 tjedna i 4 dana $(31+4 / 7)$, visoka $154 \mathrm{~cm}$, tjelesne težine od $75 \mathrm{~kg}$ (+9 kg tijekom trudnoće), s dotad urednim tijekom trudnoće. Pri rutinskome ginekološkom pregledu žalila se na bol u području simfize tijekom duljeg vremena, s pogoršanjem u posljednja 3 tjedna, uz teškoće hodanja i stajanja u uspravnom položaju. Manualnom palpacijom dijagnosticiran je interpubični razmak od $10 \mathrm{~mm}$ te je bolesnica hospitalizirana. U dotadašnjoj povijesti bolesti kao jedini komorbiditeti spominjale su se blaga anemija, liječena preparatima željeza, i trombocitopenija poznata od djetinjstva. Tijekom hospitalizacije liječena je konzervativnim metodama koje 


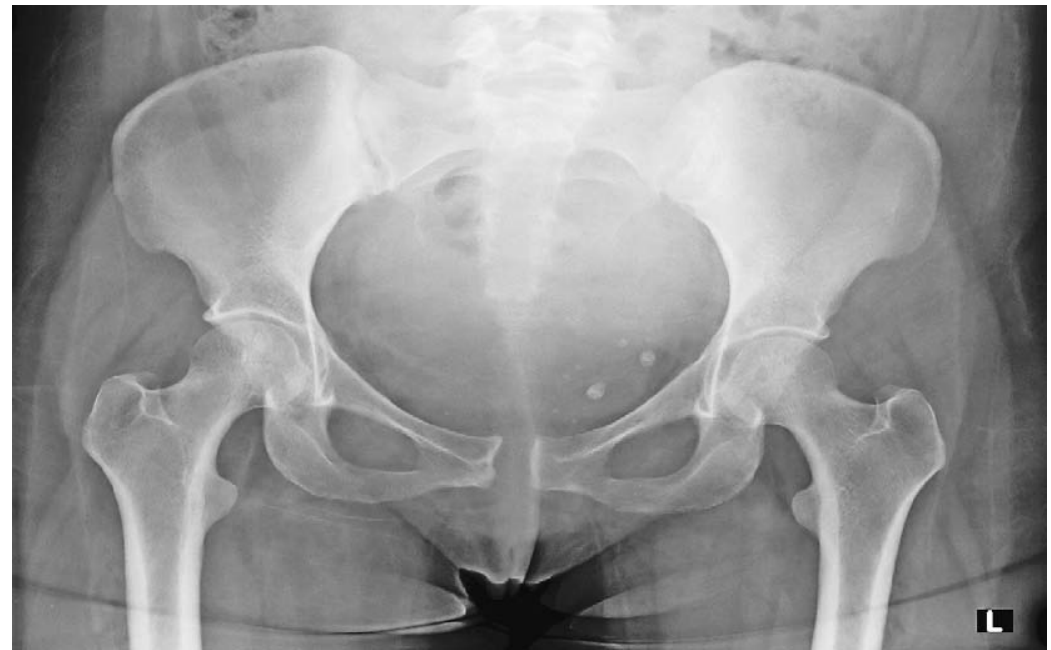

Figure 1. Pelvic X-ray after delivery showing a 14-mm intrapubic gap SLIKA 1. Nativni rendgenogram zdjelice nakon porođaja s vidljivim interpubičnim razmakom $(14 \mathrm{~mm})$ abdominal wall muscles), walking with crutches, walking backwards, and resting in the lateral decubitus position. Furthermore, as threatened preterm labor was noted, inhibition of acute preterm delivery was achieved with an intravenous tocolytic agent (fenoterol) administered for two days, along with stimulation of fetal lung maturation with dexamethasone $(2 \times 6 \mathrm{mg})$ for two days. In addition to that, intravenous antibiotic therapy (cefazolin) because of elevated blood inflammatory markers was administered for 6 days. Considering the twin pregnancy and pubic symphysis diastasis, it was decided that a cesarean section was the appropriate mode of delivery. Thus, at the gestational age of 36 weeks and 1 day $(36+1 / 7)$, two male eutrophic neonates (each weighing 2,500 grams and 48 centimeters long) were born with Apgar scores 10/10. The postoperative course was uneventful. A pelvic X-ray showed an interpubic gap of 14 $\mathrm{mm}$ (Figure 1). The patient's symptoms were reduced and she was discharged from hospital four days afterwards. In the routine follow-up two months after delivery she had no complaints as she was symptomless with normal mobility.

\section{DISCUSSION}

Pubic symphysis diastasis is a rare complication of pregnancy considered to be an underdiagnosed pathology without an established incidence. Although authors do not distinguish antepartum from postpartum diastasis when reporting on their incidence (1-5), the difference in the physiological conditions of the aforementioned periods is obvious, and therefore the etiology and risk factors cannot be the same. The suggested risk factors for postpartum symphysis pubis diastasis are multiparity, shoulder dystocia, macrosomic fetus, large fetal head, rapid progression of the second stage of labor and rapid descent of the presenting part, epidural anesthesia, and previous pelvic trauma. For antenatal symphysis pubis diastasis the risk factors are su uključivale nošenje zdjeličnog remena, fizioterapeutske vježbe (jačanje mišića dna zdjelice i trbušne stijenke), hod sa štakama, hodanje unatrag i odmor u bočnome dekubitalnom položaju. Nadalje, budući da je primijećena prijetnja od prijevremena porođaja, provedene su inhibicija akutnoga prijevremenog porođaja intravenskim tokolitičkim sredstvom (fenoterolom) tijekom 2 dana i stimulacija fetalnog sazrijevanja pluća deksametazonom $(2 \times 6 \mathrm{mg})$. Zbog povišenih vrijednosti upalnih markera provedena je parenteralna antimikrobna terapija antibiotikom cefazolinom tijekom 6 dana. S obzirom na blizanačku trudnoću i dijastazu pubične simfize, zaključili smo da je carski rez pravilan način porođaja. Rođena su dva muška novorođenčeta s Apgarinom ocjenom 10/10 u gestacijskoj dobi od 36 tjedana i 1 dana $(36+1 / 7)$, eutrofična, oba tjelesne mase od 2500 grama i dužine od 48 centimetara. Postoperativni tijek protekao je bez teškoća. Obavljen je rendgenogram (RDG) zdjelice koji je pokazao interpubični razmak od $14 \mathrm{~mm}$ (slika 1.). Pacijentičini simptomi ublažili su se pa je nakon 4 dana otpuštena iz bolnice. Dva mjeseca poslije, pri rutinskome kontrolnom pregledu pacijentica je negirala sve prijašnje simptome i bila uredne pokretljivosti.

\section{RASPRAVA}

Dijastaza pubične simfize rijetka je komplikacija trudnoće i smatra se nedovoljno dijagnosticiranom patologijom bez utvrđene učestalosti. Iako autori, kad prijavljuju incidenciju $(1-5)$, ne razlikuju antepartalnu dijastazu od postpartalne, razlika u fiziološkim uvjetima tijekom tih razdoblja očita je pa stoga etiologija i čimbenici rizika ne mogu biti isti. Predloženi rizični čimbenici za postpartalnu dijastazu pubične simfize jesu multiparitet, distocija ramena, makrosomni fetus, velika glava fetusa, brzo napredovanje druge faze porođaja i brzo spuštanje prezentacijskog dijela, epiduralna anestezija te prethodna trauma zdje- 
macrosomic fetus, similar difficulties in a previous pregnancy, primiparity, and twin pregnancy. While all other risk factors are speculative, twin pregnancy and primiparity are the only ones proven statistically (2). On the other hand, this distinction can be argued, claiming that is the same continuous pathologic condition with a different timing of manifestation.

Since most of the risk factors of this disorder are speculative, its etiology is unclear and unproven as well. The theory of relaxin-induced laxity of ligaments and joints which could cause pelvic instability and symphyseal separation has not yielded its final conclusion, as published studies report contrary findings $(7,10,12,13)$.

Different terms can be found describing the clinical presentation of pain in the symphyseal region that radiates to the lower back and thighs, waddling gait, painful movement, and reduced mobility in pregnancy or postpartum: symphysis rupture, birth-associated pelvic pain, postpartum pelvic instability, pelvic insufficiency, separated public symphysis, pubic symphysis pain, symphysis pubis dysfunction, symphyseolysis during pregnancy, pubic symphysis diastasis, and symptomatic pelvic girdle relaxation of pregnancy (3, 7). However, only pubic symphysis diastasis is defined by precise imaging findings. The increasing distance between the pubic bones during pregnancy as a preparation for delivery is a physiological process. Reported values of physiological interpubic gap during pregnancy vary among studies $(4,6,8,14)$, but the cut-off value of $10 \mathrm{~mm}$ defines pubic symphysis diastasis and differentiates physiological from pathological symphysis separation. The interpubic gap can be measured by ultrasound $(5,14), \mathrm{X}$ ray $(6), \mathrm{MRI}(8)$, or CT (4). There is no superiority of one imaging procedure over the others $(3,7)$. Furthermore, several studies demonstrated no relation between the interpubic gap size and the severity of clinical findings $(4,6,8,15)$. Therefore, clinical findings should be the main focus and imaging workup should be used for confirmation. Pelvic pain, as a nonspecific symptom, cannot be a pathognomonic sign of diastasis symphysis, but with other typical signs and symptoms, and after excluding common causes of pregnancy-related pelvic pain, educated and aware professionals should suspect pubic symphysis diastasis. After an assumption is made, the confirmation should be easy. Manual palpation as the first step in the workup is an easy, fast, and inexpensive method, as we reported in our case. Therefore, we suggest implementing symphysis palpation in regular obstetric practice in cases of suspected pubic symphysis diastasis.

There are no official guidelines regarding the mode of delivery in women with pubic symphysis diastasis. Most authors recommend an individualized approach $(3,7)$. In this particular case, considering the twin pregnancy which usually involves $\mathrm{C}$-section in our obstetric practice, and the diastasis, we decided that a C- lice. Za antepartalnu dijastazu pubične simfize čimbenici rizika jesu makrosomni fetus, slične teškoće $u$ prethodnoj trudnoći, primiparitet i blizanačka trudnoća. Iako se o svim ostalim čimbenicima rizika može raspravljati, blizanačka trudnoća i primiparitet jedini su statistički potvrđeni (2). S druge strane, ova se razlika može argumentirati tvrdnjom da je to isto kontinuirano patološko stanje, ali s različitim vremenom manifestacije. Budući da je većina rizičnih čimbenika prijeporna, etiologija stanja također je nejasna i nedovoljno dokazana. Teorija o opuštenosti ligamenata i zglobova izazvanoj relaksinom, koja bi mogla prouzročiti nestabilnost zdjelice i razdvajanje simfize, nije dala konačan zaključak jer provedene studije izvještavaju o proturječnim nalazima $(7,10,12,13)$. Postoje različiti pojmovi koji opisuju kliničku prezentaciju boli u području simfize koja se širi u donji dio leđa i bedra, gegavi hod, bolne pokrete i smanjenu pokretljivost $\mathrm{u}$ trudnoći ili nakon porođaja: puknuće simfize, bol u zdjelici povezana s porođajem, postpartalna nestabilnost zdjelice, insuficijencija zdjelice, odvojena pubična simfiza, bol u pubičnoj simfizi, disfunkcija pubične simfize, simfizeoliza tijekom trudnoće, dijastaza pubične simfize, simptomatsko opuštanje zdjeličnog pojasa u trudnoći $(3,7)$. Međutim, jedino je dijastaza pubične simfize definirana preciznim slikovnim nalazima. Povećavanje udaljenosti između stidnih kosti tijekom trudnoće fiziološki je proces pripreme za porođaj. Izvještavane vrijednosti fiziološkog interpubičnog razmaka tijekom trudnoće razlikuju se ovisno o studiji $(4,6,8,14)$, ali granična vrijednost od $10 \mathrm{~mm}$ definira dijastazu pubične simfize i razlikuje fiziološko razdvajanje simfize od patološkoga. Interpubični razmak može se izmjeriti ultrazvukom $(5,14)$, x-zrakama (6), magnetskom rezonancijom (MR) (8) ili kompjutoriziranom tomografijom (CT) (4). Nijedan slikovni postupak ne nadmašuje ostale $(3,7)$. Nadalje, nekoliko studija nije pokazalo povezanost između veličine interpubičnog razmaka i težine kliničkog nalaza $(4,6,8,15)$. Stoga bismo se morali usredotočiti ponajprije na kliničke nalaze, a slikovna bi obrada trebala služiti za potvrdu. Bol u zdjelici, kao nespecifičan simptom, ne može biti patognomoničan znak dijastaze simfize, ali uz ostale tipične znakove i simptome, a nakon isključivanja uobičajenih uzroka boli u zdjelici povezanih $s$ trudnoćom, obrazovani i svjesni stručnjaci trebali bi postaviti sumnju na dijastazu pubične simfize. Nakon pretpostavke potvrda bi trebala biti jednostavna. Manualna palpacija, kao prvi korak u obradi, jednostavna je, brza i jeftina metoda, što smo već naveli u svojem prikazu bolesnice. Stoga predlažemo uvođenje palpacije simfize u redovitu opstetričku praksu pri sumnji na dijastazu pubične simfize. Ne postoje službene smjernice o načinu porođaja u žena s dijastazom pubične simfize. Većina autora preporučuje individualizi- 
section was a pain free, long-term beneficial mode of delivery. In general, pregnancy-related antepartum pubic symphysis diastasis is an insufficiently investigated condition, with unanswered questions about its exact incidence, risk factors, and prevention, and without evidence-based guidelines for the workup, treatment, and mode of delivery.

\section{CONCLUSION}

With regard to the simplicity and reliability of manual palpation in cases of suspected pubic symphysis diastasis, implementing palpation of the pubis in regular obstetrical practice would enable early recognition, immediate treatment, and a better long-term outcome. Also, antepartum pubic symphysis diastasis should be considered with regards to the mode of delivery. As there are no evidence-based guidelines and each case is approached individually, a comprehensive investigation of this condition is needed, with the aim to achieve standardization of practice.

Conflict of interest statement: Authors declare no conflict of interest.

Prijevod na hrvatski/Translated on Croatian IvANA JEŽIĆ

\section{REFERENCES / LITERATURA}

1. Shnaekel KL, Magann EF, Ahmadi S. Pubic Symphysis Rupture and Separation During Pregnancy. Obstet Gynecol Surv. 2015; 70(11):713-8.

2. Yoo JJ, Ha Y-C, Lee Y-K, Hong JS, Kang B-J, Koo K-H. Incidence and risk factors of symptomatic peripartum diastasis of pubic symphysis. J Korean Med Sci. 2014;29:281-6.

3. Herren C, Sobottke R, Dadgar A i sur. Peripartum pubic symphysis separation - Current strategies in diagnosis and therapy and presentation of two cases. Injury. 2015;46:1074-80. Dostupno na: http://dx.doi.org/10.1016/j.injury.2015.02.030. Pristupljeno: 1. 10. 2019.

4. Scriven MW, Jones DA, McKnight L. The importance of public pain following childbirth: A clinical and ultrasonographic study of diastasis of the pubic symphysis. J R Soc Med. 1995; 88(1):28-30.

5. Chawla JJ, Arora D, Sandhu N, Jain M, Kumari A. Pubic symphysis diastasis: A case series and literature review. Oman Med J. 2017;32:510-4.

6. Hagen R. Pelvic girdle relaxation from an orthopaedic point of view. Acta Orthop Scand. 1974;45:550-63.

7. Owens K, Pearson A, Mason G. Pubic symphysis separation. Fet Matern Med Rev. 2002;13:141-55.

8. Wurdinger S, Humbsch K, Reichenbach JR, Peiker G, Seewald HJ, Kaiser WA. MRI of the pelvic ring joints postpartum: Nor- ran pristup $(3,7)$. U konkretnom slučaju naše bolesnice, a s obzirom na blizanačku trudnoću, kojoj se u našoj opstetričkoj praksi obično pristupa carskim rezom, i dijastazu, zaključili smo da je carski rez bezbolan način porođaja s dugotrajnom dobrobiti. Općenito, antepartalna dijastaza pubične simfize povezana s trudnoćom nedovoljno je istraženo stanje, bez odgovora na pitanja o točnoj incidenciji, rizičnim čimbenicima i prevenciji te bez smjernica utemeljenih na dokazima za njezinu obradu i liječenje, kao i način porođaja.

\section{ZAKLJUČAK}

S obzirom na jednostavnost i pouzdanost manualne palpacije pri sumnji na dijastazu pubične simfize, uvođenje palpacije stidnih kosti u redovitu opstetričku praksu omogućilo bi rano prepoznavanje stanja, neposredno liječenje i dugoročno bolji ishod. Također, valjalo bi donijeti preporuke o načinu porođaja pri antepartalnoj dijastazi pubične simfize. Budući da ne postoje smjernice utemeljene na dokazima, nego se svakoj bolesnici pristupa individualizirano, potrebno je sveobuhvatno istraživanje ovog stanja koje bi dovelo do standardiziranja prakse.

Izjava o sukobu interesa: Autori izjavljuju da nisu u sukobu interesa. mal and pathological findings. J Magn Reson Imaging. 2002; 15:324-9.

9. Young J. Relaxation of the Pelvic Joints in Pregnancy: Pelvic Arthropathy of Pregnancy. J Obstet Gynecol Br Emp. 1940;47: 493-524.

10. Kristiansson P, Svärdsudd K, von Schoultz B. Serum relaxin, symphyseal pain, and back pain during pregnancy. Am J Obstet Gynecol. 1996;175:1342-7.

11. MacLennan AH, MacLennan SC. Symptom-giving pelvic girdle relaxation of pregnancy, postnatal pelvic joint syndrome and developmental dysplasia of the hip. Acta Obstet Gynecol Scand. 1997;76:760-4.

12. Hansen A, Jensen DV, Larsen E, Wilken-Jensen C, Petersen LK. Relaxin is not related to symptom-giving pelvic girdle relaxation in pregnant women. Acta Obstet Gynecol Scand. 1996; 75:245-9.

13. MacLennan AH, Nicolson R, Green RC, Bath M. Serum relaxin and pelvic pain of pregnancy. Lancet. 1986;2(8501):243-5.

14. Topuz S, Citil I, Iyibozkurt AC, Dursun M. Pubic symphysis diastasis: imaging and clinical features. Eur J Radiol Extra. 2006;59:127-9.

15. Schwartz Z, Katz Z, Lancet M. Management of puerperal separation of the symphysis pubis. Int J Gynaecol Obstet. 1985; 23:125-8. 